\title{
Aptamer-Functionalized Gold Nanoparticles for Turn-On Light Switch Detection of Platelet-Derived Growth Factor
}

\author{
Chih-Ching Huang, ${ }^{\dagger}$ Sheng-Hsien Chiu, ${ }^{\dagger}$ Yu-Fen Huang, ${ }^{\dagger}$ and Huan-Tsung Chang*,t,‡ \\ Department of Chemistry, National Taiwan University, 1, Section 4, Roosevelt Road, Taipei 106, Taiwan, and \\ Department of Natural Science Education, National Taitung University, Taitung, Taiwan
}

An aptamer modified gold nanoparticles (Apt-AuNPs) based molecular light switching sensor has been demonstrated for the analysis of breast cancer markers (plateletderived growth factors (PDGFs) and their receptors) in homogeneous solutions. The PDGF binding aptamer has a unique structure with triple-helix conformation that allows $N, N$-dimethyl-2,7-diazapyrenium dication (DMDAP) and PDGF bindings. The fluorescence of DMDAP is almost completely quenched by Apt-AuNPs when it intercalates with the aptamers. Owing to high magnitudes of increases (up to 40-fold) in the turn-on fluorescence signals of DMDAP/Apt-AuNP upon PDGFs binding, the approach is highly sensitive for the detection of PDGFs. The DMDAP/Apt-AuNP probe specifically and sensitively detected PDGFs under optimal concentrations of salts and DMDAP. We also demonstrated that the AptAuNPs are effective selectors for enrichment of PDGFAA from large-volume samples. The approach allows detection of PDGF-AA at a concentration down to $8 \mathrm{pM}$, showing better sensitivity than other signal aptamers. By conducting a competitive assay, we demonstrated the determination of PDGF receptor- $\alpha$ with LOD of $0.25 \mathrm{nM}$ when using the DMDAP/Apt-AuNP as a probe.

As complements to antibody-based sensors, molecular probes based on nucleic acid platforms are emerging. One of the representative examples is the use of aptamers for protein analysis. ${ }^{1}$ DNA and RNA sequences recognizing specific target analytes are called aptamers that are isolated from randomsequence DNA or RNA libraries by in vitro selection or systematic evolution of ligands by exponential enrichment (SELEX). ${ }^{2}$ In comparison to antibodies, aptamers are advantageous because

* To whom correspondence should be addressed. Tel and fax: 011-886-2 33661171, E-mail; changht@ntu.edu.tw.

$\dagger$ National Taiwan University.

* National Taitung University.

(1) (a) Proske, D.; Blank, M.; Buhmann, R.; Resch, A. Appl. Microbiol. Biotechnol. 2005, 69, 367-374. (b) Nutiu, R.; Li, Y. Methods 2005, 37, 16-25. (c) Tombelli, S.; Minunni, M.; Mascini, M. Biosens. Bioelectron. 2005, 20, 24242434. (d) Famulok, M.; Mayer, G.; Blind, M. Acc. Chem. Res. 2000, 33, 591-599. (e) Bunka, D. H. J.; Stockley, P. G. Nat. Rev. Microbiol. 2006, 4, $588-596$.

(2) (a) Joyce, G. F. Gene 1989, 82, 83-87. (b) Ellington, A. D.; Szostak, J. W. Nature 1990, 346, 818-822. (c) Tuerk, C.; Gold, L. Science 1990, 249, $505-510$. they can be engineered not only to detect nucleic acid targets but also to recognize a broad scope of non-nucleic acid analytes, including proteins and metabolites. ${ }^{2-8}$ In addition, aptamers are more easily labeled with signal moieties such as fluorophores and enzymes. Further, they are more stable and are of a relatively lower cost. ${ }^{3}$ Several strategies for transducing aptamer-target interactions into the changes in colorimetric, ${ }^{4}$ electrochemical, ${ }^{5}$ mechanical, ${ }^{6}$ piezoelectric, ${ }^{7}$ or fluorescent ${ }^{3}$ signals and in electrophoretic mobility ${ }^{8}$ have been reported. Among these methods, fluorescence signaling is the most desirable, because of the convenience of detection (diverse measurement methods) and availability of numerous fluorophores and quenchers for nucleic acid modification., 3

The changes in fluorescence intensity, lifetime, and anisotropy of fluorophore-labeled aptamers resulting from the changes in the microenvironment or rotational motion through their interactions with target analytes are common detection modes. ${ }^{3,9}$ In addition, intermolecular and intramolecular fluorescence resonance energy transfer (FRET) between the donor and acceptor through specific binding of fluorophore-labeled aptamers toward target analytes is sensitive and of interest. ${ }^{9}$ However, tedious processes for labeling the aptamers or target analytes and the use of expensive fluorophores or coupling reagents are required. In addition, the

(3) Nutiu, R.; Li, Y. Chem. Eur. J. 2004, 10, 1868-1876.

(4) (a) Stojanovic, M. N.; Landry, D. W. J. Am. Chem. Soc. 2002, 124, 9678 9679. (b) Ho, H.-A.; Leclerc, M. J. Am. Chem. Soc. 2004, 126, 1384-1387. (c) Liu, J.; Lu, Y. Angew. Chem., Int. Ed 2006, 45, 90-94. (d) Liu, J.; Lu, Y. Adv. Mater. 2006, 18, 1667-1671.

(5) (a) Floch, F. L.; Ho, H. A.; Leclerc, M. Anal. Chem. 2006, 78, 4727-4731 (b) Fahlman, R. P.; Sen, D. J. Am. Chem. Soc 2002, 124, 4610-4616. (c) Baker, B. R.; Lai, R. Y.; Wood, M. S.; Doctor, E. H.; Heeger, A. J.; Plaxco, K. W. J. Am. Chem. Soc. 2006, 128, 3138-3139. (d) Lai, R. Y.; Plaxco, K. W.; Heeger, A. J. Anal. Chem. 2007, 79, 229-233.

(6) Fritz, J.; Baller, M. K.; Lang, H. P.; Rothuizen, H.; Vettiger, P.; Meyer, E.; Güntherodt, H.-J.; Gerber Ch Gimzewski, J. K. Science 2000, 288, 316318

(7) Tombelli, S.; Minunni, M.; Luzi, E.; Mascini, M. Bioelectrochemistry 2005 , 67, 135-141.

(8) (a) Haes, A. J.; Giordano, B. C.; Collins, G. E. Anal. Chem. 2006, 78, 37583764. (b) Buchanan, D. D.; Jameson, E. E.; Perlette, J.; Malik, A.; Kennedy, R. T. Electrophoresis 2003, 24, 1375-1382. (c) Huang, C.-C.; Cao, Z.; Chang, H.-T.; Tan, W. Anal. Chem. 2004, 76, 6973-6981.

(9) (a) Yang, C. J.; Jockusch, S.; Vicens, M.; Turro, N. J.; Tan, W. Proc. Natl. Acad. Sci. U.S.A. 2005, 102, 17278-17283. (b) Katilius, E.; Katiliene, Z.; Woodbury, N. W. Anal. Chem. 2006, 78, 6484-6489. (c) Pavlov, V.; Shlyahovsky, B.; Willner, I. J. Am. Chem. Soc. 2005, 127, 6522-6523. (d) Gokulrangan, G.; Unruh, J. R.; Holub, D. F.; Ingram, B.; Johnson, C. K.; Wilson, G. S. Anal. Chem. 2005, 77, 1963-1970. (e) Nutiu, R.; Li, Y. J. Am. Chem. Soc. 2003, 125, 4771-4778. 


\section{Scheme 1. Schematic Representations of PDGF Nanosensors That Operate Based on Modulation of the FRET between DMDAP and Apt-AuNPsa}

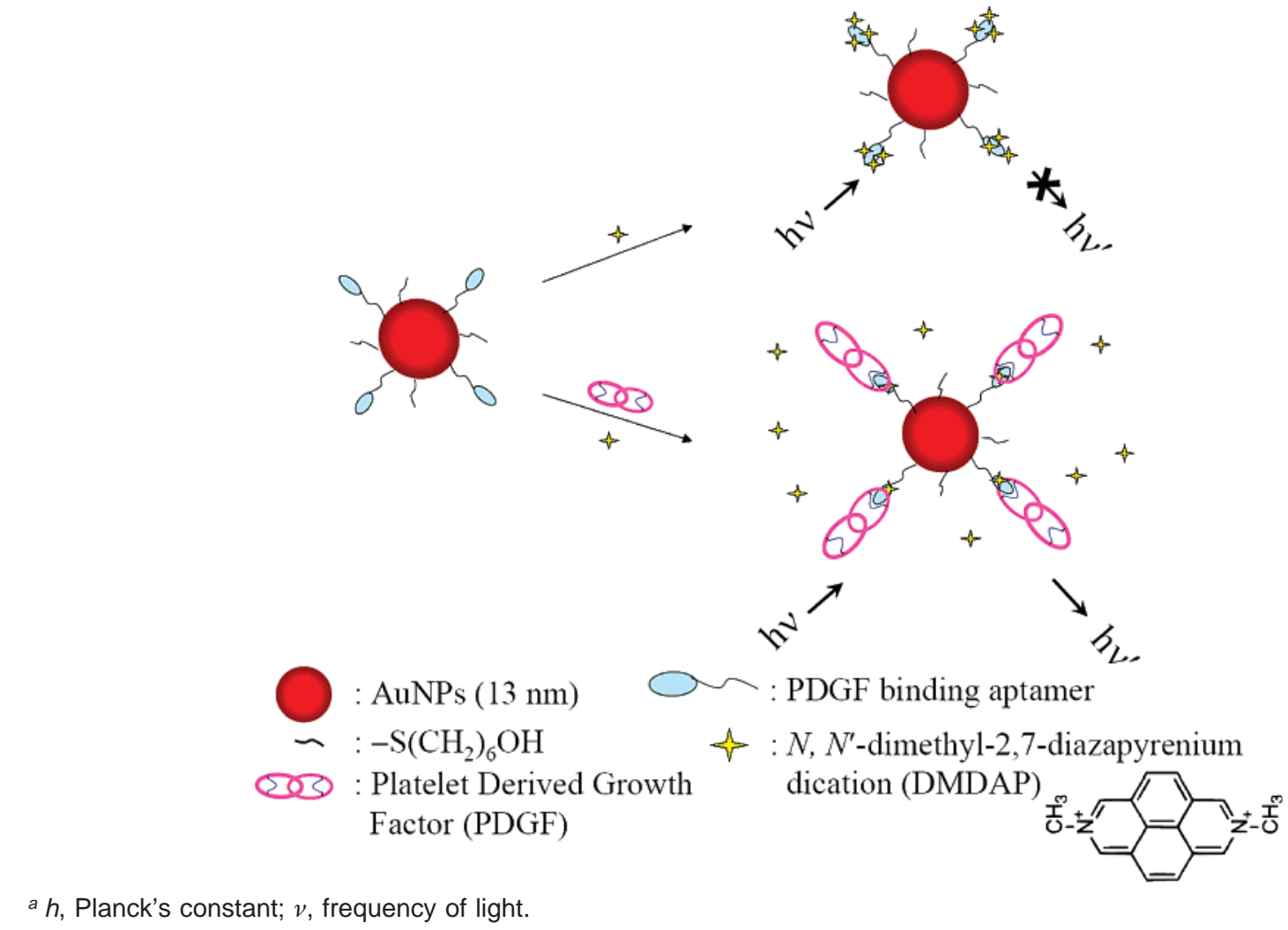

precise target binding sites and the resulting conformational changes of the aptamers are generally unknown; thus, it is not easy to design labeling strategies. To circumvent these disadvantages, a covalent label-free aptamer probe using DNA intercalating dyes such as $\left[\mathrm{Ru}(\mathrm{phen})_{2}(\mathrm{dppz})\right]^{2+}$ or TOTO has been demonstrated for the detection of target analytes, mainly because of their simplicity and high sensitivity. ${ }^{10}$ The fluorescence of the dye is strong when intercalating to an aptamer, but decreases with increasing protein concentration as a result of changes or distortion in the aptamer conformation. However, this method is a turn-off fluorescence assay that is usually less sensitive when compared to turn-on assays. Herein, a new strategy for detection of proteins using aptamer modified Au nanoparticles (Apt-AuNPs) through a turn-on fluorescence switching mechanism was demonstrated. Our representative target protein is platelet-derived growth factor (PDGF) that is a growth factor protein in human platelets and has growth-promoting activity for fibroblasts, smooth muscle cells, and glial cells. ${ }^{11}$ We used a fluorophore $N, N$-dimethyl2,7-diazapyrenium dication (DMDAP) that has a binding affinity $\left(3.2 \times 10^{5} \mathrm{M}^{-1}\right)$ to DNA. ${ }^{12}$ The fluorescence (excitation and

(10) (a) Jiang, Y.; Fang, X.; Bai, C. Anal. Chem. 2004, 76, 5230-5235. (b) Zhou, C.; Jiang, Y.; Hou, S.; Ma, B.; Fang, X.; Li, M. Anal. Bioanal. Chem. 2006, $384,1175-1180$.

(11) (a) Hart, C. E.; Bailey, M.; Curtis, D. A.; Osborn, S.; Raines, E.; Ross, R.; Forstrom, J. W. Biochemistry 1990, 29, 166-172. (b) Lubinus, M.; Meier, K. E.; Smith, E. A.; Gause, K. C.; LeRoy, E. C.; Trojanowska, M. J. Biol. Chem. 1994, 269, 9822-9825. (c) Koempel, J. A.; Gibson, S. E.; O'Grady, K.; Toriumi, D. M. Int. J. Pediatr. Otorhinolaryngol. 1998, 46, 1-8. (d) Bentas, W.; Beecken, W.-D.; Glienke, W.; Binder, J.; Schuldes, H. Urol. Res. 2003, 30, 390-393.

(12) (a) Becker, H.-C.; Nordén, B. J. Am. Chem. Soc. 1997, 119, 5798-5803. (b) Brun, A. M.; Harriman, A. J. Am. Chem. Soc. 1992, 114, 3656-3660.

emission wavelengths are 335 and $424 \mathrm{~nm}$, respectively) of DMDAP changes slightly upon intercalation with DNA. When adding DMDAP to Apt-AuNP solution, it intercalates with the aptamers. Consequently, its fluorescence is almost completely quenched by Apt-AuNPs through FRET, electron transfer, and collision processes as depicted in Scheme $1 .{ }^{13}$ The fluorescence of DMDAP strong restored upon protein binding to Apt-AuNPs, mainly because distortion in the aptamer conformation occurred or the intercalation access to DMDAP was blocked.

\section{EXPERIMENTAL SECTION}

Materials. The 5'thiol-modified PDGF binding aptamer (5'CAG GCT ACG GCA CGT AGA GCA TCA CCA TGA TCC TG$3^{\prime}$ ), $\alpha$-thrombin binding aptamer (5'-ACC CGT GGT AGG GTA GGA TGG GGT GGT-3'), and the randomly selected oligonucleotide (control) having the sequence 5'-CAG CGT ACG GCA CGT ACC GAT TCA CCA TGA AGC TG-3' were purchased from Integrated DNA Technology, Inc. (Coralville, IA). Recombinant human PDGF-AA, PDGF-BB, PDGF-AB, and PDGF receptors (PDGFR- $\alpha$ and $-\beta$ ) were purchased from R\&D Systems Inc. (Minneapolis, MN). PDGFs were dissolved in $4 \mathrm{mM} \mathrm{HCl}$ containing $0.1 \%$ bovine serum albumin (BSA), whereas PDGFRs were prepared in $5 \mathrm{mM}$ PBS (pH 7.4; $135 \mathrm{mM} \mathrm{NaCl})$. Proteins including BSA, myoglobin, carbonic anhydrase, $\beta$-lactablumin, trypsin inhibi-

(13) (a) Kamat, P. V.; Barazzouk, S.; Hotchandani, S. Angew. Chem., Int. Ed. 2002, 41, 2764-2767. (b) Dulkeith, E.; Morteani, A. C.; Niedereichholz, T.; Klar, T. A.; Feldmann, J.; Levi, S. A.; van Veggel, F. C. J. M.; Reinhoudt, D. N.; Möller, M.; Gittins, D. I. Phys. Rev. Lett. 2002, 89, 203002. (c) Huang, T.; Murray, R. W. Langmuir 2002, 18, 7077-7081. (d) Fan, C.; Wang, S.; Hong, J. W.; Bazan, G. C.; Plaxco, K. W.; Heeger, A. J. Proc. Natl. Acad. Sci. U.S.A. 2003, 100, 6297-6301. 
tor, $\beta$-casein, ribonuclease $\mathrm{A}$, trypsinogen, and lysozyme were obtained from Sigma (St. Louis, MO). Hydrogen tetrachloroaurate(III) trihydrate and all other reagents used in this study were purchased from Aldrich (Milwaukee, WI). DMDAP was synthesized and purified according to the literature. ${ }^{14}$

Synthesis of AuNPs. AuNPs were prepared by citrate reduction of $\mathrm{HAuCl}_{4} \cdot{ }^{15} \mathrm{~A} 250$-mL aqueous solution consisting of $1 \mathrm{mM}$ $\mathrm{HAuCl}_{4}$ was brought to a vigorous boil and stirred in a roundbottom flask fitted with a reflux condenser, and then $38.8 \mathrm{mM}$ trisodium citrate $(25 \mathrm{~mL})$ was added rapidly to the solution. The solution was boiled for another $15 \mathrm{~min}$, during which time its color changed from pale yellow to deep red. The solution was cooled to room temperature with continuous stirring. The sizes of the nanoparticles were verified by TEM (H7100, Hitachi HighTechnologies Corp., Tokyo, Japan); they appeared to be nearly monodispersed, with an average size of $13.3 \pm 1.2 \mathrm{~nm}$. A doublebeam UV-vis spectrophotometer (Cintra 10e, GBC, Victoria Australia) was used to measure absorption of the AuNP solution. The particle concentration of the AuNPs $(\sim 15 \mathrm{nM})$ was determined according to Beer's law using an extinction coefficient of $\sim 10^{8} \mathrm{M}^{-1} \mathrm{~cm}^{-1}$ at $520 \mathrm{~nm}$ for AuNPs of 13.3-nm diameter. ${ }^{15 \mathrm{c}}$

Preparation of Apt-AuNPs. The two thiol-modified 35-mer DNA oligonucleotides were attached to the AuNPs according to modified literature procedures. ${ }^{16}$ The 5 'thiol-modified oligonucleotides were received in a disulfide form $\left[\mathrm{HOCH}_{3}\left(\mathrm{CH}_{2}\right)_{5} \mathrm{~S}-\right.$ $\mathrm{S}-5$-oligo], protected by a mercaptohexanol group. These oligonucleotides were reacted directly with the AuNPs through attachment of both the $\mathrm{HOCH}_{3}\left(\mathrm{CH}_{2}\right)_{5} \mathrm{~S}$ - and oligo-S- units onto the AuNP surface. Two aliquots of aqueous AuNP solutions (800 $\mu \mathrm{L}$ ) in a $1.5-\mathrm{mL}$ tube were mixed separately with the thiooligonucleotides $(5.0 \mu \mathrm{M}, 200 \mu \mathrm{L})$ to obtain a final concentration of 12 $\mathrm{nM}$ AuNPs and $1.0 \mu \mathrm{M}$ oligonucleotides. After reaction for $24 \mathrm{~h}$ at room temperature, the mixtures were centrifuged for $25 \mathrm{~min}$ at $16000 \mathrm{rpm}$ to remove the excess thiol-DNA. Following removal of the supernatants, the oily precipitates were washed with $4 \mathrm{mM}$ trisodium citrate. After two wash/centrifuge cycles, the Apt-AuNPs and oligo-AuNPs were resuspended separately in $4 \mathrm{mM}$ trisodium citrate and stored in a refrigerator $\left(4^{\circ} \mathrm{C}\right)$. Finally, the Apt-AuNPs and oligo-AuNPs (control) were equilibrated separately with $0.1 \%$ BSA for $120 \mathrm{~min}$ at room temperature before use for detecting PDGFs. The BSA-modified, Apt-AuNPs can prevent nonspecific binding with interference proteins. ${ }^{17}$ Moreover, the Apt-AuNPs were stable in solutions containing up to $3.0 \mathrm{M} \mathrm{NaCl} .{ }^{17}$ To determine the number of oligos on each AuNP, a solution of 2-mercaptoethanol (1.0 M, $10 \mu \mathrm{L})$ was used to displace the oligonucleotide molecules from the surface of the AuNPs (12 nM,

(14) (a) Hünig, S.; Gross, J.; Lier, E. F.; Quast, H. Liebigs Ann. Chem. 1973, 339-358. (b) Blacker, A. J.; Jazwinski, J.; Lehn, J.-M. Helv. Chim. Acta 1987, $70,1-12$.

(15) (a) Frens, G. Nat. Phys. Sci. 1973, 241, 20-22. (b) Grabar, K. C.; Freeman, R. G.; Hommer, M. B.; Natan, M. J. Anal. Chem. 1995, 67, 735-743. (c) Mucic, R. C.; Storhoff, J. J.; Mirkin, C. A.; Letsinger, R. L. J. Am. Chem. Soc. 1998, 120, 12674-12675.

(16) (a) Storhoff, J. J.; Elghanian, R.; Mucic, R. C.; Mirkin, C. A.; Letsinger, R. L. J. Am. Chem. Soc. 1998, 120, 1959-1964. (b) Otsuka, H.; Akiyama, Y.; Nagasaki, Y.; Kataoka, K. J. Am. Chem. Soc. 2001, 123, 8226-8230. (c) Obare, S. O.; Hollowell, R. E.; Murphy, C. J. Langmuir 2002, 18, 1040710410. (d) Thanh, N. T. K.; Rosenzweig, Z. Anal. Chem. 2002, 74, 16241628. (e) Hirsch, L. R.; Jackson, J. B.; Lee, A.; Halas, N. J.; West, J. L. Anal. Chem. 2003, 75, 2377-2381.

(17) Huang, C.-C.; Huang, Y.-F.; Cao, Z.; Tan, W.; Chang, H.-T. Anal. Chem. 2005, $77,5735-5741$.
$990 \mu \mathrm{L})$. The amount of displaced oligonucleotide in the supernatant was used to calculate its quantity on each AuNP particle. ${ }^{16}$ Our calculations indicated that $\sim 40$ oligonucleotide molecules were attached to each AuNP.17

Fluorescence Assays. Aliquots ( $1 \mathrm{~mL}$ ) of $0.05 \mathrm{M}$ PBS (5 mM sodium phosphate and $50 \mathrm{mM} \mathrm{NaCl} ; \mathrm{pH}$ 7.4) solutions containing PDGFs $(0-20 \mathrm{nM})$ and DMDAP $(2 \mathrm{nM})$ in the presence of AptAuNPs $(0.05 \mathrm{nM})$ were maintained at room temperature for $1 \mathrm{~h}$. All solutions were then transferred into a 1-mL quartz cuvette, and their fluorescence spectra were measured using a Hitachi F-4500 fluorescence spectrophotometer with excitation at $335 \mathrm{~nm}$.

Competitive Assays of PDGF Receptors. Aliquots (1 mL) of $0.05 \mathrm{M}$ PBS solutions containing PDGFs (2 nM), Apt-AuNPs $(0.05 \mathrm{nM})$, and DMDAP (2 nM) in the presence of PDGFR- $\alpha$ or $-\beta(5 \mathrm{nM})$ were maintained at room temperature for $1 \mathrm{~h}$. All solutions were then transferred into 1-mL quartz cuvettes, and their fluorescence spectra were measured using a fluorescence spectrophotometer with excitation wavelength at $335 \mathrm{~nm}$.

\section{RESULTS AND DISCUSSION}

DMDAP/Apt-AuNP-Based Sensor for PDGF. The SternVolmer quenching constant values of dyes-AuNP pairs are usually several orders of magnitude greater than those of typical small-molecule dye-quencher pairs. ${ }^{13}$ This superquenching property of AuNPs is employed to be effective proximal quenchers in the optical detection of DNA through hybridization with a complimentary DNA modified AuNPs and in the optical detection of antigens through highly specific affinity with antibodies modified AuNPs. ${ }^{18}$ DMDAP and PDGF compete to interact with the aptamer molecules on AuNP surfaces. Although the aptamer molecules are single-stranded DNA, they fold into unique threedimensional structures through base pairing to ensure their specific binding to PDGF. ${ }^{19}$ With increasing PDGF concentration, less DMDAP molecules bind to Apt-AuNPs. As a result, the fluorescence of the solution is stronger at a higher PDGF concentration (Scheme 1).

Intercalation of DMDAP with Apt-AuNPs. To test our concept, a series of solutions as described in Figure 1 were prepared. Figure 1 (spectra a-c) shows that the Apt and PDGFAA both do not alter the fluorescence spectrum of DMDAP. We note that there are three isoforms of PDGFs, including PDGFAA, PDGF-AB, and PDGF-BB. ${ }^{20}$ This result suggested that DMDAP does not intercalate strongly with the aptamer and PDGFAA under the experimental conditions. It has been reported that the fluorescence of DMDAP decreases slightly upon intercalation with DNA. ${ }^{12}$ On the other hand, the fluorescence decreases dramatically as depicted in spectrum d (Figure 1) once DMDAP binds to Apt-AuNPs. The fluorescence intensity of DMDAP at 424 $\mathrm{nm}$ reached a state of equilibrium in $\sim 20 \mathrm{~min}$. The equilibrium time is longer than that of the intercalation between DMDAP and aptamer in free solution, due mainly to diffusion of DMDAP toward the Apt-AuNP surface where the intercalation took place and to

(18) (a) Maxwell, D. J.; Taylor, J. R.; Nie, S. J. Am. Chem. Soc. 2002, 124, 96069612. (b) Dubertret, B.; Calame, M.; Libchaber, A. J. Nat. Biotechnol. 2001 , 19, 365-370. (c) Li, H.; Rothberg, L. J. Anal. Chem. 2004, 76, 5414-5417. (d) Ao, L.; Gao, F.; Pan, B.; He, R.; Cui, D. Anal. Chem. 2006, 78, $1104-$ 1106.

(19) Green, L. S.; Jellinek, D.; Jenison, R.; Östman, A.; Heldin, C.-H.; Janjic, N. Biochemistry 1996, 35, 14413-14424.

(20) Meyer-Ingold, W.; Eichner, W. Cell Biol. Int. 1995, 19, 389-398. 


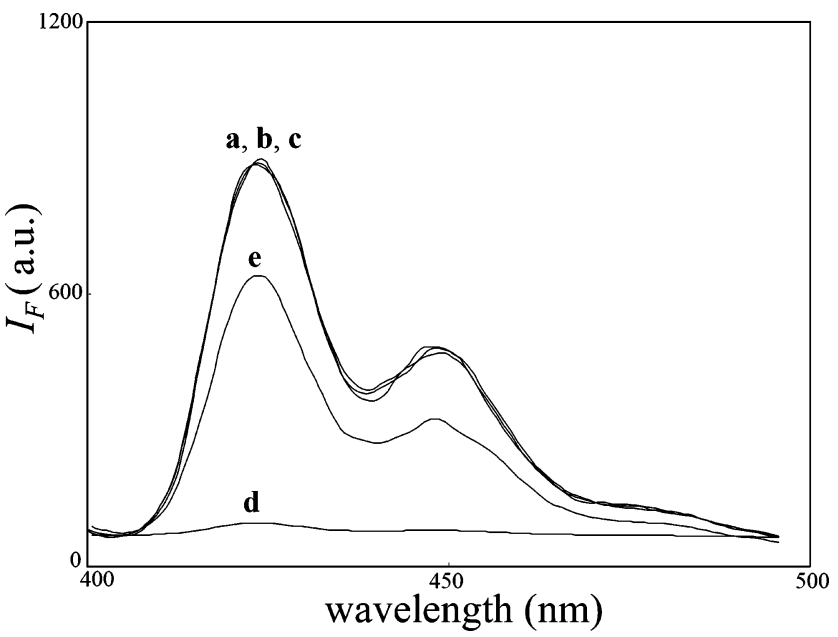

Figure 1. Fluorescence spectra for solutions of (a) DMDAP $(2 \mathrm{nM})$; (b) mixture of PDGF binding aptamer (2 nM) and DMDAP (2 nM); (c) mixture of PDGF binding aptamer (2 nM), DMDAP (2 nM) and PDGFAA (2 nM); (d) mixture of Apt-AuNP (0.05 nM) and DMDAP (2 nM); and (e) mixture of Apt-AuNP (0.05 nM), DMDAP (2 nM), and PDGFAA (2 nM). Buffer: $50 \mathrm{mM} \mathrm{NaCl}, 5 \mathrm{mM}$ sodium phosphate, $\mathrm{pH} 7.4$. Excitation wavelength: $335 \mathrm{~nm}$. The fluorescence intensities are plotted in arbitrary units (au).

changes in aptamer conformation on the solid surface. By collecting the fluorescence intensities $\left(I_{\mathrm{F}}\right)$ of DMDAP at different concentrations of Apt-AuNPs, a plot of $1 / I_{\mathrm{F}}$ versus $\left[\mathrm{P}_{\mathrm{tot}}\right] /\left(I_{\mathrm{F} 0}-\right.$ $I_{\mathrm{F}}$ ) was established, which allows estimation of the binding affinity of Apt-AuNPs to DMDAP to be $\sim 3.0 \times 10^{8} \mathrm{M}^{-1}$ (Figure S1; see Supporting Information). This binding constant provides 3 orders of magnitude higher than the simple DMDAP-DNA binding, ${ }^{12}$ which is likely due to the multivalent binding effect (ultrahigh densities of Apt on the local surface of AuNPs). ${ }^{21}$ By adding 2 nM PDGF-AA to a mixture containing Apt-AuNPs and DMDAP, the fluorescence at $424 \mathrm{~nm}$ increased (spectrum e), indicating greater amounts of DMDAP remaining in the bulk solution. PDGF-AA induced rearrangement of the loop-stem structure of the aptamer or blocked the intercalation access to DMDAP, leading to weak interactions of Apt-AuNPs with DMDAP. This aptamer sequence was obtained through the SELEX process and was reported to have 700-fold higher affinity for PDGF when compared with other random DNA sequences. ${ }^{19}$ Another controlled experiment using random-sequence control DNA labeled AuNP $(0.05 \mathrm{nM})$ was performed to highlight the specificity of the Apt-AuNPs to PDGF-AA. As expected, PDGF-AA does not induce fluorescence change, showing no or very weak interactions between random-sequence control DNA labeled AuNPs and PDGF-AA.

Interaction of Dyes with Apt-AuNPs. We further compared the impact that some DNA binding dyes, including DMDAP, acridin orange, acridin blue, picogreen, YOYO-3, and ethidium bromide, and DNA nonbonding dyes, including fluorescein and rhodamine $\mathrm{B}$, have on the determination of PDGF-AA using AptAuNPs. Of these, the sensitivity of PDGF-AA is best in the

(21) (a) Nolting, B.; Yu, J.-J.; Liu, G.-Y.; Cho, S.-J.; Kauzlarich, S.; Gervay-Hague, J. Langmuir 2003, 19, 6465-6473. (b) Verma, A.; Rotello, V. M. Chem. Commun. 2005, 303-312. (c) Ipe, B. I.; Yoosaf, K.; Thomas, K. G. J. Am. Chem. Soc. 2006, 128, 1907-1913. (d) Wang, G.; Zhang, J.; Murray, R. W. Anal. Chem. 2002, 74, 4320-4327. (e) Verma, A.; Nakade, H.; Simard, J. M.; Rotello, V. M. J. Am. Chem. Soc. 2004, 126, 10806-10807.

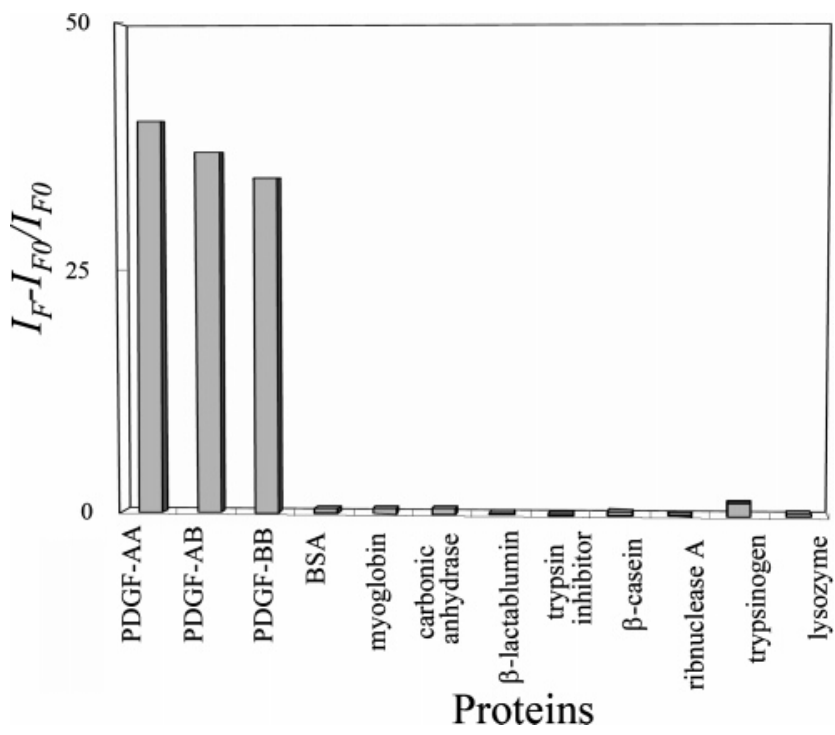

Figure 2. Relative fluorescence increases $\left(I_{F}-I_{F 0} / I_{F 0}\right)$ at $424 \mathrm{~nm}$ of the DMDAP/Apt-AuNP probe $(0.05 \mathrm{nM})$ to PDGF-AA, -AB, and -BB, BSA, myoglobin, carbonic anhydrase, $\beta$-lactablumin, trypsin inhibitor, $\beta$-casein, ribonuclease $\mathrm{A}$, trypsinogen, and lysozyme. The concentrations of all proteins and DMDAP were $2 \mathrm{nM}$. Other conditions are the same as those described in Figure 1.

DMDAP/Apt-AuNP system (Figure S2; see Supporting Information). All DNA binding dyes provided almost no fluorescent background upon binding with Apt-AuNPs, however, fluorescence restores were only found in the solutions containing DMDAP, acridin orange, and acridin blue. On the contrary, picogreen, YOYO-3, and ethidium bromide binding to Apt-AuNPs were found under the experimental conditions; however, no restoration of the fluorescence was observed after adding PDGF-AA. This is due to the very low fluorescence intensity of the dyes (picogreen, YOYO3 , ethidium bromide) alone in solutions. Fluorescein and rhodamine $\mathrm{B}$ did not bind to the Apt-AuNPs and the aptamer under the experimental conditions, and thus, their fluorescence backgrounds were high and no restoration was observed after adding PDGFAA.

Selectivity of DMDAP/Apt-AuNPs. Figure 2 demonstrates that the Apt-AuNP has high specificity toward its target proteins. Aliquots of the mixture of DMDAP (2 nM) and Apt-AuNP (0.05 $\mathrm{nM}$ ) were incubated with either PDGFs or some possible interfering proteins, including BSA, myoglobin, carbonic anhydrase, $\beta$-lactablumin, trypsin inhibitor, $\beta$-casein, ribonuclease $\mathrm{A}$, trypsinogen, and lysozyme, in biological samples such as blood. The relative responses to fluorescence changes of the interfering protein are negligible when compared to those from PDGFs. The basic proteins such as trypsinogen and lysozyme that might have electrostatic interactions with the negatively charged Apt-AuNPs did not cause interference, further showing the specificity of the present probe. Interestingly, this order of sensitivity does not correlate with the stability order of the Apt-PDGF complexes in free solutions: PDGF-BB > PDGF-AB > PDGF-AA, ${ }^{19}$ which agrees with our previously reported result. ${ }^{17}$ The different stability order is likely due to the changes in the structures of aptamer, PDGFs, or both on the AuNP surface and differences in the nature of the nonspecific interactions between the PDGFs and AptAuNPs. We note that the molecular masses of PDGF-AA, -AB, 

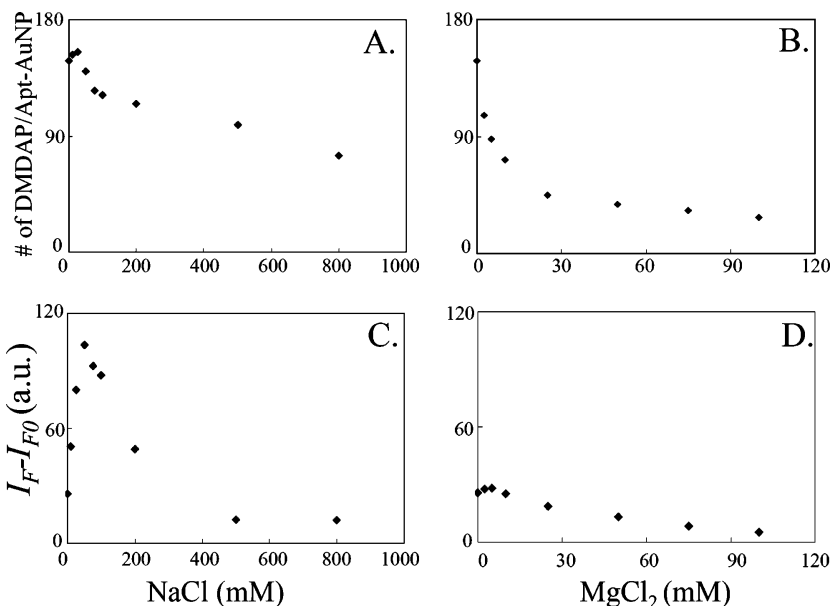

Figure 3. Effects of salts on the binding ratio of DMDAP to AptAuNPs and the fluorescence increase $\left(I_{F}-l_{F 0}\right)$ at $424 \mathrm{~nm}$ of DMDAP/ Apt-AuNP for PDGF-AA (2 nM). The concentrations of DMDAP and Apt-AuNP were $10 \mathrm{nM}$ and $0.05 \mathrm{nM}$, respectively. Buffer: $5 \mathrm{mM}$ sodium phosphate, $\mathrm{pH}$ 7.4. Other conditions are the same as those described in Figure 1.

and $-\mathrm{BB}$ are $2.9 \times 10^{4}, 2.7 \times 10^{4}$, and $2.5 \times 10^{4} \mathrm{~g} / \mathrm{mol}$, respectively. ${ }^{20}$

Optimizing Conditions. It is well-known that the dye/DNA and protein/DNA interactions are affected by some key factors, such as the $\mathrm{pH}$ and ionic strength of the buffer. ${ }^{9,10}$ The buffer and its $\mathrm{pH}$ value (7.4) we used above were chosen to provide favorable binding of PDGFs to the aptamer according to the SELEX selection. ${ }^{19}$ At $\mathrm{pH}$ 7.4, we investigated the salt effect on the sensitivity of PDGF-AA using Apt-AuNPs and DMDAF. It is known that the affinity of DMDAP to DNA decreases with increasing buffer salt concentration. ${ }^{12 a}$ As shown in Figure $3 \mathrm{~A}$ and $\mathrm{B}, \mathrm{NaCl}$ and $\mathrm{MgCl}_{2}$ have different impacts on the binding affinity of DMDAP to Atp-AuNP in the buffers. The salt impact on changing the Apt-AuNP stability is neglected since Apt-AuNPs are stable in high-salt media up to $3 \mathrm{M} .{ }^{17}$ The binding ratio of DMDAP to Apt-AuNP always decreased with increasing $\mathrm{Mg}^{2+}$ concentration, while upon increasing $\mathrm{Na}^{+}$concentration, the ratio increased to over $0-25 \mathrm{mM}$ and then decreased at a concentration higher than $25 \mathrm{mM}$. A small amount of $\mathrm{Na}^{+}$is beneficial for stabilization of a unique triple-helix conformation of the folded aptamer, resulting in better DMDAP intercalation. ${ }^{19}$ Since intercalation of DMDAP to DNA involves favorable electrostatic interactions, ${ }^{12 a}$ high concentrations of metal ions are expected to reduce the electrostatic forces between the negatively charged DNA bone and the positively charged DMDAP. The role that salt plays in determining the sensitivity of PDGF-AA is relatively complicated since it also affects the interaction between the aptamer and PDGF-AA. According to the SELEX selection study, sodium phosphate buffer (pH 7.4) containing $137 \mathrm{mM} \mathrm{NaCl}$ and $1.0 \mathrm{mM}$ $\mathrm{MgCl}_{2}$ is proper. ${ }^{19}$ Panels $\mathrm{C}$ and $\mathrm{D}$ in Figure 3 separately show that the optimum $\mathrm{NaCl}$ and $\mathrm{MgCl}_{2}$ concentrations are 50 and 5 $\mathrm{mM}$, respectively. Increases in the $\mathrm{Mg}^{2+}$ concentration have a greater effect on the disruption of signal enhancement of mixture of DMDAP induced by PDGF-AA than do increases in $\mathrm{Na}^{+}$ concentration. These results agree with our previous observations that divalent ions like $\mathrm{Mg}^{2+}$ have a stronger impact on the binding strength of aptamers to proteins than do monovalent ions like
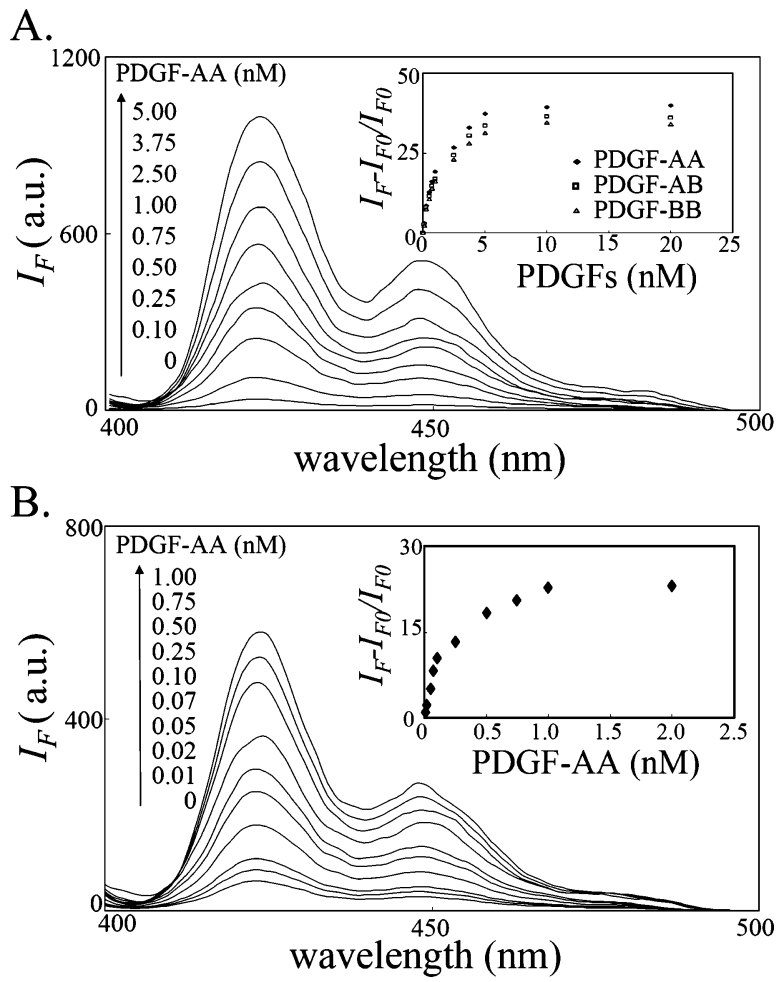

Figure 4. Validation of the use of DMDAP/Apt-AuNPs as (A) probes for PDGFs and (B) selectors and probes for PDGF-AA. The concentrations of DMDAP and Apt-AuNP in (A) were 2 and $0.05 \mathrm{nM}$, respectively. (B) Apt-AuNPs (5 pM) were used to selectively enrich PDGF-AA (10 pM-2 nM), and then the enriched PDGF-AA solutions were analyzed. Other conditions are the same as those described in Figure 1.

$\mathrm{Na}^{+} \cdot{ }^{17}$ This phenomenon is due mainly to the fact that $\mathrm{Mg}^{2+}$ has a greater affinity to the phosphate groups on the DNA backbone than does PDGF-AA (pI 9.8). ${ }^{22}$ The fluorescence of DMDAP is highly quenched by $\mathrm{Mg}^{2+}$ in free solution; for example, the fluorescence is quenched at least by $50 \%$ in the presence of $5 \mathrm{mM}$ $\mathrm{MgCl}_{2}$ (data not shown). Thus, the studies following this herein were performed in $5 \mathrm{mM}$ phosphate buffer ( $\mathrm{pH}$ 7.4) containing $50 \mathrm{mM} \mathrm{NaCl}$ without any $\mathrm{Mg}^{2+}$. We further investigated the effect of DMDAP concentration on sensing PDGF-AA using Apt-AuNPs. The fluorescence signals of DMDAP/Apt-AuNP increase with increasing concentrations of PDGF-AA at different DMDAP concentrations (Figure S3; see Supporting Information). The signal enhancement ratios $\left(I_{\mathrm{F}}-I_{\mathrm{F} 0} / I_{\mathrm{F} 0}\right)$ decrease through increasing the concentration of DMDAP from 2 to $20 \mathrm{nM}$ under the same PDGFAA concentration, mainly due to a smaller fluorescence background of the solutions at a slower concentration of DMDAP. Although the limit of detection (LOD) is lower at a lower DMDAP concentration, a narrower dynamic detection region for PDGFAA was observed. When using $2 \mathrm{nM}$ DMDAP and $0.05 \mathrm{nM}$ AptAuNPs, the detection dynamic range for PDGF-AA was from 0.1 to $5 \mathrm{nM}$.

PDGFs and Thrombin Detecting. Using an optimum buffer (sodium phosphate $5 \mathrm{mM}, \mathrm{pH} 7.4, \mathrm{NaCl} 50 \mathrm{mM}$ and DMDAP 2 $\mathrm{nM})$, the calibration curves of PDGFs using an Apt-AuNP sensor $(0.05 \mathrm{nM})$ are exhibited in Figure 4A. The linear relationships

(22) Antoniades, H. N.; Scher, C. D.; Stiles, C. D. Proc. Natl. Acad. Sci. U.S.A. 1979, 76, 1809-1813. 
for all three PDGFs were from 0.1 to $1.0 \mathrm{nM}$, with the correlation coefficients being greater than 0.96 . The LODs for PDGF-AA, $-\mathrm{AB}$, and -BB were experimentally determined to be 65,75 , and $90 \mathrm{pM}$, respectively, based on a signal-to-noise ratio $(\mathrm{S} / \mathrm{N})$ of 3 . These LODs for PDGFs were comparable with those using other signaling aptamer reporters. ${ }^{9 a, b, 10,17}$ This highly sensitive detection of PDGFs by DMDAP/Apt-AuNP is due to a very low background signal and large signal enhancement up to 40-fold upon addition of PDGF at the saturated concentration.

To further improve the sensitivity of the DMDAP/Apt-AuNP system, we used a nanoparticles-assisted protein enrichment method. ${ }^{23}$ Some recent reports have shown that nanomaterials such as AuNPs are good capturers of biomolecules. ${ }^{23 b, \mathrm{~d}, \mathrm{f}} \mathrm{A}$ series of mixtures $(1 \mathrm{~mL})$ of PDGF $(10 \mathrm{pM}-2 \mathrm{nM})$ and Apt-AuNP (5 $\mathrm{pM}$ ) in buffers (sodium phosphate $5 \mathrm{mM}, \mathrm{pH} 7.4, \mathrm{NaCl} 50 \mathrm{mM}$ ) were placed at $25^{\circ} \mathrm{C}$ for $1 \mathrm{~h}$. Subsequently, the mixtures were centrifuged and the supernatants were removed. Finally, the precipitates were resuspended with $100 \mu \mathrm{L}$ of buffer $(\mathrm{pH}$ 7.4) of $5 \mathrm{mM}$ sodium phosphate, $0.1 \mathrm{mM}$ sodium citrate, $50 \mathrm{mM} \mathrm{NaCl}$, and $2 \mathrm{nM}$ DMDAP, and then the solutions stayed for another 1 $h$. The fluorescence spectra of various PDGF-AA solutions were recorded as shown in Figure 4B. These show that the fluorescence responses increase with increasing PDGF-AA concentration. The linear relationship of the signal enhancement ratios $\left(I_{\mathrm{F}}-I_{\mathrm{F} 0} / I_{\mathrm{F} 0}\right)$ against PDGF-AA concentration as shown in the inset of Figure $4 \mathrm{~B}$ was from 0.0 to $0.25 \mathrm{nM}$, with the correlation coefficient of 0.98 and the LOD at S/N 3 of PDGF-AA experimentally determined to be $8 \mathrm{pM}$. This Apt-AuNP-assisted PDGF-AA enrichment provided near one order greater sensitivity improvements than the above result.

To illustrate whether our new signaling strategy is applicable to the detection of other proteins, another 27-nt DNA aptamer binding to the exosite II of $\alpha$-thrombin (an endoprotease protein that has many effects in the coagulation cascade) was tested. ${ }^{24}$ This aptamer has a unique structure with G-quartet conjugated stem base pairs that allow DMDAP and $\alpha$-thrombin bindings. Similarly, a linear relationship of the fluorescence intensity versus the concentration of $\alpha$-thrombin was obtained when $\alpha$-thrombin was added to the DMDAP/Apt-AuNP solutions (Figure S4; see Supporting Information). The linear calibration curve for $\alpha$-thrombin quantitation were from 0.5 to $10 \mathrm{nM}$, with the correlation coefficient of 0.95 . The LOD at S/N 3 of $\alpha$-thrombin was determined to be $0.25 \mathrm{nM}$.

Competitive Assay. The three isomeric PDGF molecules bind specifically at different degrees to two receptors, namely, the PDGF $\alpha$ - and $\beta$-receptors. ${ }^{25}$ The dissociation constants $\left(K_{\mathrm{d}}\right)$ for the complexes of PDGF receptor- $\alpha$ (PDGFR- $\alpha$ ) with PDGF-BB, $-\mathrm{AB}$, and $-\mathrm{AA}$ are $0.5,0.1$, and $0.2 \mathrm{nM}$, respectively. ${ }^{20,25,26}$ Although PDGFR- $\beta$ binds both PDGF-BB and PDGF-AB with high affinities

(23) (a) Zheng, M.; Huang, X. J. Am. Chem. Soc. 2004, 126, 12047-12054. (b) Teng, C.-H.; Ho, K.-C.; Lin, Y.-S.; Chen, Y.-C. Anal. Chem. 2004, 76, 43374342. (c) Kong, X. L.; Huang, L. C. L.; Hsu, C.-M.; Chen, W.-H.; Han, C.-C.; Chang, H.-C. Anal. Chem. 2005, 77, 259-265. (d) Wang, A.; Wu, C.-J.; Chen, S.-H. J. Proteome Res. 2006, 5, 1488-1492. (e) Kriz, K.; Ibraimi, F.; Lu, M.; Hansson, L.-O.; Kriz, D. Anal. Chem. 2005, 77, 5920-5924. (f) Huang, Y.F.; Chang, H.-T. Anal. Chem. 2006, 78, 1485-1493.

(24) (a) Bock, L. C.; Griffin, L. C.; Latham, J. A.; Vermaas, E. H.; Toole, J. J. Nature 1992, 355, 564-566. (b) Tasset, D. M.; Kubik, M. F.; Steiner, W. J. Mol. Biol. 1997, 272, 688-698.

(25) Hart, C. E.; Forstrom, J. W.; Kelly, J. D.; Seifert, R. A.; Smith, R. A.; Ross, R.; Murray, M. J.; Bowen-Pope, D. F. Science 1988, 240, 1529-1531.

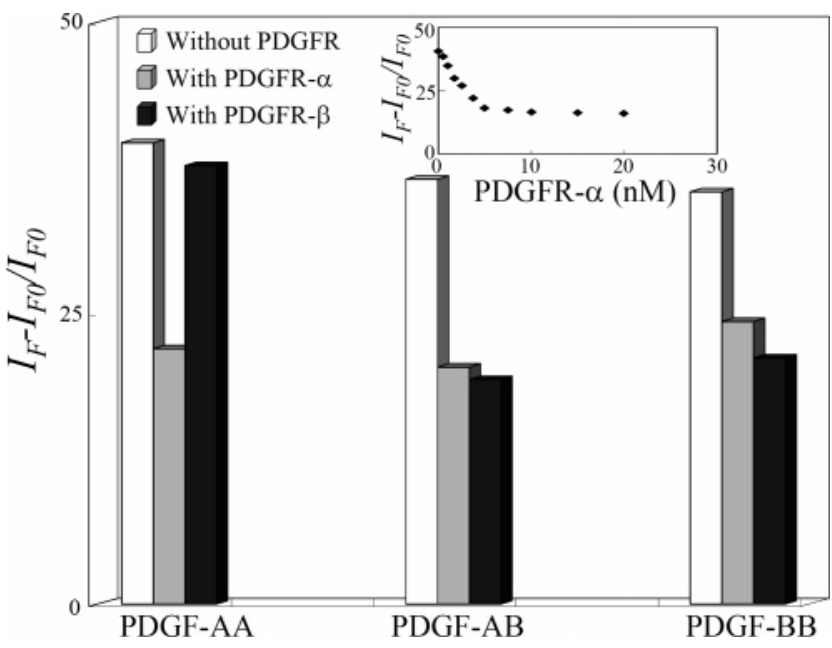

Figure 5. Competitive binding assay for $P D G F$ receptors using the DMDAP/Apt-AuNP probe. PDGF-AA, -AB, and -BB were mixed separately with PDGFR- $\alpha$ or $-\beta$ in $5 \mathrm{mM}$ sodium phosphate $(\mathrm{pH} 7.4)$ containing $50 \mathrm{mM} \mathrm{NaCl}$ at room temperature for $1 \mathrm{~h}$ prior to reaction with the DMDAP/Apt-AuNPs. The inset shows the calibration curve of DMDAP/Apt-AuNP/PDGF-AA solutions by PDGFR- $\alpha(0-20 \mathrm{nM})$. The final concentrations of PDGFs, DMDAP, and Apt-AuNP were 2, 2 , and $0.05 \mathrm{nM}$, respectively. Other conditions are the same as those described in Figure 1.

$\left(K_{\mathrm{d}}=0.5 \mathrm{pM}\right.$ and $1-2.5 \mathrm{nM}$, respectively), it has no appreciable affinity for PDGF-AA. ${ }^{20,25,26}$ Binding of the receptors to PDGF is known to activate intracellular tyrosine kinase, leading to autophosphorylation of the cytoplasmic domain of the receptor as well as phosphorylation of other intracellular substrates. ${ }^{27}$ It is known that the aptamer can inhibit the binding of PDGFs to PDGFR and suppress the regulation of PDGFR. ${ }^{19,28}$ Therefore, we believed that addition of the PDGFR to solutions of the DMDAP/Apt-AuNPs and PDGFs would alter the degree of fluorescence increases that are induced by PDGFs. To test this hypothesis, we conducted a competitive assay using the Apt-AuNPs. As indicated in Figure 5, the degree of signal increases in the solutions of DMDAP and Apt-AuNPs $(0.05 \mathrm{nM})$ induced by PDGF-AA, -AB, and -BB $(2 \mathrm{nM})$ reduced upon mixing with PDGFR- $\alpha$. On the other hand, PDGFR- $\beta$ only caused the reduction of fluorescence increases in the solutions of DMDAP and Apt-AuNPs induced by PDGF-AB and -BB. We stress that the control proteins, such as BSA, carbonic anhydrase, trypsin inhibitor, and trypsinogen, did not affect the interaction between PDGFs and PDGFRs (data not shown). These results reveal that the disruptions of the interactions between PDGFs and PDGFRs were due mainly to competition between PDGFRs and the Apt-AuNPs for PDGFs, which are in good agreement with our previous report. ${ }^{17}$ On the basis of the titration curve (inset of Figure 5) of the solutions containing DMDAP, AptAuNPs, and PDGF-AA (2 nM) against PDGF- $\alpha(0-20 \mathrm{nM})$, we estimated the LOD for PDGFR- $\alpha$ to be $0.25 \mathrm{nM}(\mathrm{S} / \mathrm{N}=3)$ and the linear relationship of the relative fluorescence decreased the DMDAP/Apt-AuNP against PDGFR- $\alpha$ concentration was $0.5-5.0$ $\mathrm{nM}$ (correlation coefficient, 0.97 ).

(26) Seifert, R. A.; van Koppen, A.; Bowen-Pope, D. F. J. Biol. Chem. 1993, 268, 4473-4480.

(27) (a) Bishayee, S.; Majumdar, S.; Scher, C. D.; Khan, S. Mol. Cell. Biol. 1988, 8, 3696-3702. (b) Keating, M. T.; Escobedo, J. A.; Williams, L. T. J. Biol. Chem. 1988, 263, 12805-12808.

(28) Floege, J.; Ostendorf, T.; Janssen, U.; Burg, M.; Radeke, H. H.; Vargeese, C.; Gill, S. C.; Green, L. S.; Janjić, N. Am. J. Pathol. 1999, 154, 169-179. 
Biological Sample. To test the practicality of this present method, serum-free conditioned media (Dulbecco's Modified Eagle's Medium) were collected from human breast carcinoma, HTB-26. It has been reported that PDGFs secrete in culture media at the level of $0.2 \mathrm{nM} .^{29}$ Many tumor cell lines have since been shown to produce and secrete PDGFs, some of which also express the cognate PDGF receptors; the paracrine effect on the tumor stroma and, in some tumor cell lines, autocrine growth stimulation by PDGF are therefore possible..$^{29,30}$ The collected cell media were spiked with various concentrations of PDGF-AA, and the proteins were isolated using centrifugal filters (molecular weight cutoff, $10000)$, and then resuspended in $5 \mathrm{mM}$ sodium phosphate $(\mathrm{pH}$ 7.4) containing $50 \mathrm{mM} \mathrm{NaCl}$. The fluorescence responses of DMDA/Apt-AuNP in collected protein solutions is shown in Figure S5 (see Supporting Information). We achieved the recovery of $94 \%$ for PDGF-AA by the present approach. The LOD at S/N 3 for PDGF-AA spiked in HTB-26 cell media was to be $1.0 \mathrm{nM}$. The relatively high LOD value of this approach for the cell media when compared to the standard sample is mainly due to the higher background fluorescence from collected proteins in the cell culture, which was evident from the fluorescence spectra depicted in Figure S5. Although the BSA-stabilized Apt-AuNPs are stable for at least $6 \mathrm{~h}$ in the presence of deoxyribonuclease I at the concentration $50 \mathrm{ng} / \mathrm{mL}$ (usually less than $50 \mathrm{ng} / \mathrm{mL}$ in biological samples), the result suggests that preconcentration processes of large volumes of samples and selective isolation of basic PDGF proteins by conducting ion-exchange chromatography or using magnetic beads are still required to determine the concentrations of PFGF in the cell media, prior to conducting the present method.

\section{CONCLUSIONS}

We have shown a DMDAP/Apt-AuNPs-based molecular light switching sensor for the analysis of PDGFs and PDGFRs in

(29) Bronzert, D. A.; Pantazis, P.; Antoniades, H. N.; Kasid, A.; Davidson, N.; Dickson, R. B.; Lippman, M. E. Proc. Natl. Acad. Sci. U.S.A. 1987, 84, 57635767.

(30) (a) Sebti, S. M.; Hamilton, A. D. Oncogene 2000, 19, 6566-6573. (b) Corless, C. L.; Fletcher, J. A.; Heinrich, M. C. J. Clin. Oncol. 2004, 22, 3813-3825. homogeneous solutions. The method takes advantages of high magnitudes of increases in the turn-on fluorescence signals of DMDAP/Apt-AuNP upon PDGFs binding. The DMDAP/AptAuNP probe specifically and sensitively detected PDGFs under optimal concentrations of salts and DMDAP. We also demonstrated that the Apt-AuNPs are effective selectors for enrichment of PDGF-AA from large-volume samples. The approach allows detection of PDGF-AA at a concentration down to $8 \mathrm{pM}$, which is more sensitive than using other signal aptamers. ${ }^{9 a, b, 10,17}$ By conducting a competitive assay, we demonstrated the determination of PDGFR- $\alpha$ using the DMDAP/Apt-AuNP as a probe. With the advantages of simplicity and specificity, the present approach holds great potential for protein analysis and cancer diagnosis, but preconcentration of the target proteins such as PDGFs from biological samples such as blood by conducting ion-exchange chromatography or using magnetic microbeads is required.

\section{ACKNOWLEDGMENT}

This study was supported by the National Science Council of Taiwan under contracts NSC 95-2113-002-026-MY3) C.-C.H. acknowledges the PDF support from National Taiwan University.

\section{SUPPORTING INFORMATION AVAILABLE}

Fluorescence titration of DMDAP with Apt-AuNP (Figure S1). Relative fluorescence increases of solutions containing different fluorophores and Apt-AuNP following the addition of PDGF-AA (Figure S2). Relative fluorescence increases of different solutions containing DMDAP $(2-20 \mathrm{nM})$ and Apt-AuNP after addition of PDGF-AA (Figure S3). Validation of the use of DMDAP/AptAuNPs as probes for $\alpha$-thrombin (Figure S4). Validation of the use of DMDAP/Apt-AuNPs as probes for PDGF-AA (0-30 nM) spiked in cultured cell media (Figure S5). This material is available free of charge via the Internet at http://pubs.acs.org.

Received for review April 10, 2007. Accepted April 22, 2007.

AC0707075 